\title{
A PICTURE OF WOMEN'S ENTREPRENEURSHIP: A FIELD STUDY ON MOTIVATION FACTORS, REGIONAL DIFFERENCES and VALUE PERCEPTIONS
}

\section{DOI: 10.17261/Pressacademia.2017.471}

RJBM- V.4-ISS.2-2017(8)-p.160-169

\author{
Sevgi Kesim Guven ${ }^{1}$, Tamer Atabarut ${ }^{2}$, Aylin Lole ${ }^{3}$ \\ ${ }^{1}$ Bogazici University Lifelong Learning Centre, kesim@boun.edu.tr \\ 2 Bogazici University Lifelong Learning Centre, atabarut@boun.edu.tr \\ 3 Bogazici University Lifelong Learning Centre, aylinlole@gmail.com
}

To cite this document

Guven, S.K., T. Atabarut and A. Lole. (2017). A picture of women's entrepreneurship: a field study on motivation factors, regional differences and value perceptions. Research Journal of Business and Management (RJBM), V.4, Iss.2, p.160-169.

Permemant link to this document: http://doi.org/10.17261/Pressacademia.2017.471

Copyright: Published by PressAcademia and limited licenced re-use rights only.

\section{ABSTRACT}

Purpose- It is a fact that the active participation of women in business life began later in developing countries. The socio-economic systems of the nations and systems of values caused this delay; however, other versions of the glass ceiling in business life exist for female entrepreneurs. The issue of female entrepreneurs is a painful issue for developing countries such as Turkey, although women's entrepreneurship is still on the rise. As well as state-sponsored projects, non-governmental organizations also try to support women's entrepreneurship.

Methodology- The materials used in this study mainly depend on the outcomes and analyses of the questionnaires administered to the aspiring female entrepreneurs who participated in educational programs in Gaziantep, İzmir, Kastamonu, Adana, Çanakkale and Konya within the corporate social responsibility project (My Idea is My Future) carried out by the Inclusive Growth Association and the Boğaziçi University Lifelong Learning Centre with the support of the Union of Chambers and Commodity Exchanges of Turkey (TOBB) and the General Directorate for SME Development (KOSGEB) and sponsorship of JTI Turkey in last two years.

Findings- This study describes the demographic characteristics of the aspiring female entrepreneurs who participated in the educational program, the attitudes towards women's entrepreneurship, the factors that obstruct entrepreneurship activities, the effects of the choice to be an entrepreneur on family roles, the preferred women entrepreneur models and women's perception of being valued.

Conclusion- These statements allow to create a picture of aspiring female entrepreneurs in different cities in Turkey and is expected to guide the planning of the next steps of other social responsibility programs.
\end{abstract}

Keywords: Entrepreneurship, female entrepreneurship, types of women in entrepreneurship, socio-economic aspects of entrepreneurship. JEL Codes: M13, J11, J16

\section{INTRODUCTION}

One of the most important indicators of a country's economic development and growth is the status of its application of an innovation-driven economic model. Needless to say, today, entrepreneurship activities form the grounds for this economic model. According to the Global Entrepreneurship Monitor $(\mathrm{GEM})^{1}$, entrepreneurship is defined as "any new business

\footnotetext{
${ }^{1}$ Global Entrepreneurship Monitor (GEM) is an academic research project initiated in 1997 by Babson College and London Business School to study the significance of entrepreneurship in the process of economic growth. Initial results of this research, which started out with 10 participant countries, were published in 1999. Since the inception of this project, 100 countries have participated in the GEM research. The
} 
establishment activity carried out by current companies, or individual(s) who are self-employed, setting up a new business or enlarging an existing business" (Karadeniz, 2014). The International Labour Organization (ILO) defines an entrepreneur as an individual who "foresees new business opportunities, builds and develops a new initiative on their own or by borrowed capital, takes potential risks and makes profit in return for all their endeavours" (Karim, 2015).

GEM's 2016 report states that innovation and intensive knowledge-based business practices take on significance in line with advances in economic development (Kelley et al., 2016). It was noted in this report that entrepreneurship's power of creating business was crucial for economic growth and stability in all parts of the world.

The growth of entrepreneurship is even more significant for developing countries and countries facing problems with generating employment. Participants of the GEM project were categorized by the World Economic Forum. According to this categorization in the 2013-2014 period, Turkey was in a transition phase, moving from the category of a productivity-driven economy to the category of an innovation-driven economy (Karadeniz, 2014). For this reason, Turkey stands out as a country wherein entrepreneurship activities and investment planning acquire even more importance.

The entrepreneurial characteristics of individuals and the development of such characteristics are extremely important factors for increasing a country's entrepreneurial performance. Hereof, the support mechanisms directed towards educating and training individuals who want to become entrepreneurs are particularly significant. In Turkey, for individuals interested in becoming entrepreneurs, their development is supported by trainings and investments provided through the cooperation of universities and industries, the latter of which includes the Small and Medium Industry Development Organization (KOSGEB).

According to the 2014 GEM report, in Turkey, during the years of 2006-2010, the average rate of individuals who wanted to become entrepreneurs was $22.67 \%$, while this rate dropped to $11.32 \%$ in 2011 . However, starting in 2012 an upward trend emerged with the rate of increasing to $31.64 \%$ in 2013. In 2014, this upward trend continued and reached to $35 \%$. During this same period, there was a decrease in women's participation in early entrepreneurship activities. In $2013,31.51 \%$ of early entrepreneurs were women, while in 2014 this rate dropped to $22.24 \%$ (Karadeniz, 2014).

As a consequence of the decrease in women entrepreneurs, the issue of women's entrepreneurship has recently become a growing topic of concern in studies centered on entrepreneur candidates. According to the review of the literature on woman's entrepreneurship, woman entrepreneurs were described as women who work either on their own, with a partner or with other people, at a work place - outside their home -established under their own names as the owner of a business. In terms of their tasks, the literature reported that women entrepreneurs carry out activities related to the production of a commodity or a service, organize the distribution, marketing and sales of these goods or services, and establish relationships with individuals, organizations or institutions necessary for her business. Furthermore, they make their own decisions about the organization of the business process, including the planning of production, operation, closure or development of the work place. Thus, a woman entrepreneur has a say over investment and the use areas of her business profit (Ecevit, 1993).

According to Moore (2000), women entrepreneurs not only establish or run a business, but also are in charge of their own careers. These new careers involve innovation, creativity, risk-taking, vision, and bravery. Women entrepreneurs are intelligent, independent and outstanding individuals, who have goals and the ability to overcome difficulties in attaining these goals. They constantly revise their expectations and business endeavours, and their social consciousness is notably high (Keskin, 2014). According to another definition, a woman entrepreneur is someone who produces and sells transferable goods or services of monetary value that are oriented directly to the market by taking calculated risks within the market economy. As owners of businesses, women entrepreneurs have a tax registration number, are registered with merchant and craftsman chambers, and are affiliated with the Confederation of Turkish Tradesmen and Craftsmen, or with the Union of Chambers and Commodity Exchanges of Turkey. They are self-employed or hire other people (Saray, 1993).

The distinction evident in definitions pertaining to women's entrepreneurship does not arise from a sexist approach, but rather from the fact that current conditions of employment are not in favour of women. Today, women are exposed to double standards in work life. This double standard is a frequently encountered condition, not only in Turkey, but also in developed countries. In order to circumvent the social and economic loss caused by this double standard, women who intend to become entrepreneurs are supported through certain initiatives, such as trainings, which are provided under both public and social responsibility projects. The data on the economic losses arising from the non-participation of women in the work force over recent years display once again the significance of this situation. According to the IMF, the exclusion of

project, which collects longitudinal data on entrepreneurship from around the world, has become the most important research project on this topic (Karadeniz, 2014). 
women from the work force in many parts of the world is harming the global economy, with some countries facing an economic loss that exceeds $30 \%$ of their gross domestic product. The IMF report shows that Turkey is at the top of the list among countries where women's contribution to the economy is not being utilized very well. In Turkey, the economic loss arising from the low female-to-male ratio in the workforce is around $25 \%$ of gross domestic product. In other words, Turkey does not make use of the economic potential of hundreds of millions of dollars that can be provided by women (Küçük, 2015). As the GEM 2015 Special Report on Women Entrepreneurs shows, if the rate of women's participation in the workforce grows, the developmental power of these economies will be higher. In addition, women's participation in the workforce is a preventive tool against poverty, because if the woman in a household works, the risk of losing all income after a negative event will decrease for all members of the household. The same report also states that the tendency of women to re-invest and transfer money towards the health, education, and nutrition of the family is higher than men (Kelley et al, 2015, Kelley et al, 2016).

This study aims to analyze the effect of the socio-economic structure of the cities where female reside on the limitations that exist for women's entrepreneurship of which main theme was given above and to make recommendations on increasing the effectiveness of educational programs on this subject. Whether the female entrepreneur candidates' motivations to be entrepreneurs, limitations, the areas in which they want to work, their choice of entrepreneur type, awareness and expectations change by region and the perception of gender roles in that region were analyzed by the study. This study analyzes the regions where the female entrepreneur candidates live, the social behavior patterns of family relationships and the entrepreneur types they prefer based on this question. The third section shows the findings of this study, and the fourth section includes the study results and recommendations. The fifth section is the discussion section.

\section{FIELD RESEARCH ON MOTIVATION FACTORS, REGIONAL DIFFERENCES AND VALUE PERCEPTIONS}

\subsection{Aim of the Research}

The aim of this research is to explore whether or not women entrepreneur candidates believe that the economic and sociocultural structure of the cities where they live has any influence on becoming entrepreneurs, and to present the expression of this perception by these women. Within this context, this research covers a number of issues, including the demographic characteristics of women entrepreneur candidates, their attitude towards women's entrepreneurship, factors restricting their entrepreneurial activities, the perceived advantages or disadvantages of the cities where they live, the effects of choosing to become entrepreneurs on their family roles and the type of entrepreneurship models that they choose.

\subsection{Scope of the Research}

The scope of this research extends to candidates participated in an educational program within the corporate social responsibility project carried out by the Inclusive Growth Association and Boğaziçi University Lifelong Learning Centre with the support of the Union of Chambers and Commodity Exchanges of Turkey (TOBB) and General Directorate for SME Development (KOSGEB) and sponsorship of JTI Turkey in last two years. As part of the project "My idea My Future" ${ }^{2}, 180$ women entrepreneur candidates participated in the training programs in 6 cities of Turkey, namely Gaziantep, Izmir, Kastamonu, Adana, Çanakkale, and Konya. The majority of participants in the training program submitted responses to the survey (74\%; n: 134).

\subsection{Research Methods}

The survey method was used for data collection, with open-ended and closed-ended questions being used in forming the surveys. These surveys were arranged as a Likert-type rating scale. Surveys used in previous research on the subject were reviewed and taken into account in forming this survey. Some questions were revised after the first implementation of the survey.

Observation and comments obtained during trainings were also used in evaluating survey data. The survey was administered at the end of trainings. In İzmir and Gaziantep, the surveys were carried out via e-mail, while in Kastamonu, Konya, Adana and Çanakkale, the surveys were carried out face-to-face.

The survey consists of three sections. The first section includes questions that serve to identify demographic and individual characteristics of the women entrepreneur candidates, while questions in the second section seek to find out women's attitudes toward entrepreneurship and the difficulties that they faced. Moreover, in this second section of the survey, there

\footnotetext{
2The CSR Project "My Idea is My Future" is designed to provide opportunities for economically disadvantaged women and to create new women entrepreneurs. The project aims to support women entrepreneur candidates who want to actively participate in economic growth, to create business in line with their entrepreneurial skills and to present a sustainable business model. In this way, the project seeks to support women on their path towards achieving equality in opportunity. http://fikrimgelecegim.com/fikrim_gelecegim_nedir.aspx
} 
are questions on the perceptions about the characteristics that a woman entrepreneur should have. The third section focuses on the relationship between family life and entrepreneurship - an area in which regional differences are believed to be most on display - effects of the region on women's entrepreneurship and the type of entrepreneurship model respondents chosen as women.

\section{RESEARCH FINDINGS AND DISCUSSIONS}

The findings obtained through the survey method were categorically classified and are shown below.

\subsection{Demographic Characteristics of Women Entrepreneur Candidates}

The demographic characteristics of women entrepreneur candidates (age, education status, work experience marital status and average number of children) are presented in Table 1 according to the cities in which the women reside.

Looking at the age profiles of the women entrepreneur candidates, it can be seen that a great majority of respondents (49\%) fall within the 35 and above age group, both on the provincial level and on the general level. This finding overlaps with the evaluations in Hisrich and Peters' study (1998), which shows that male entrepreneurs establish their first business between the ages of 25-35, while women entrepreneurs do not attain their potential of becoming entrepreneurs until between the ages of 35-45 (cited from Morçin, 2013).

The respondents living in different cities are observed to have similar rates in terms of their marital status. Overall, $65 \%$ of all respondents are married. The similarity between different cities, both in terms of respondents' age profiles and their marital status, is related to the distribution of their ages and motivation factors for getting into business life. This motivation is attributed to the fact that women respondents' desire for economic independence becomes more dominant at certain ages and during certain social periods (i.e. the desire to raise children and to make herself more independent). Data on this issue were also provided through the responses to the question on motivation factors of women entrepreneurs. Education levels indicate that the percentage of respondents with associate, graduate and postgraduate degrees is as high as $74 \%$. Furthermore, it can be seen that a great majority of respondents ( $82 \%)$ have work experience in line with their education level and age profiles. The study by Hisrich and Peters (1998) highlights that many women decide to become entrepreneurs after they quit their jobs due to high level of job dissatisfaction (cited from Morçin, 2013). This runs parallel to the findings of this study, which show that there is a high percentage of women entrepreneurs (57\%) with more than 7 years of work experience.

Table 1: Demographic Characteristics of Women Entrepreneur Candidates

\begin{tabular}{|c|c|c|c|c|c|c|c|c|c|c|c|c|c|c|c|}
\hline & \multicolumn{2}{|c|}{ Gaziantep } & \multicolumn{2}{|c|}{ İzmir } & \multicolumn{2}{|c|}{ Kastamonu } & \multicolumn{2}{|c|}{ Çanakkale } & \multicolumn{2}{|c|}{ Konya } & \multicolumn{2}{|c|}{ Adana } & \multicolumn{2}{|c|}{ General } \\
\hline & & $\mathbf{n}$ & $\%$ & $\mathbf{n}$ & $\%$ & $\mathbf{n}$ & $\%$ & $\mathbf{n}$ & $\%$ & $\mathbf{n}$ & $\%$ & $\mathbf{n}$ & $\%$ & $\mathbf{n}$ & $\%$ \\
\hline \multirow{5}{*}{ 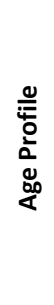 } & $18-23$ & 3 & $20 \%$ & 1 & $6 \%$ & 2 & $8 \%$ & 2 & $7 \%$ & 3 & $11 \%$ & 1 & $5 \%$ & 12 & $9 \%$ \\
\hline & $24-29$ & 4 & $27 \%$ & 3 & $19 \%$ & 5 & $21 \%$ & 4 & $14 \%$ & 8 & $28 \%$ & 2 & $9 \%$ & 26 & $20 \%$ \\
\hline & 30-35 & 2 & $13 \%$ & 2 & $13 \%$ & 6 & $25 \%$ & 6 & $21 \%$ & 12 & $43 \%$ & 2 & $9 \%$ & 30 & $22 \%$ \\
\hline & $35+$ & 6 & $40 \%$ & 10 & $62 \%$ & 11 & $46 \%$ & 17 & $58 \%$ & 5 & $18 \%$ & 17 & $77 \%$ & 66 & $49 \%$ \\
\hline & Total & 15 & $100 \%$ & 16 & $100 \%$ & 24 & $100 \%$ & 29 & $100 \%$ & 28 & $100 \%$ & 22 & $100 \%$ & 134 & $100 \%$ \\
\hline \multirow{6}{*}{ 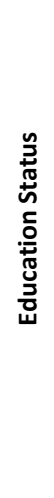 } & Primary School & 1 & $7 \%$ & & & 2 & $8 \%$ & & & 1 & $4 \%$ & 1 & $4 \%$ & 5 & $4 \%$ \\
\hline & $\begin{array}{l}\text { Secondary } \\
\text { School }\end{array}$ & 1 & $7 \%$ & & & 3 & $13 \%$ & 1 & $3 \%$ & & & & & 5 & $4 \%$ \\
\hline & High School & 5 & $33 \%$ & & & 4 & $17 \%$ & 7 & $24 \%$ & 1 & $4 \%$ & 7 & $32 \%$ & 24 & $18 \%$ \\
\hline & $\begin{array}{l}\text { Associate } \\
\text { Degree }\end{array}$ & 2 & $13 \%$ & 9 & $56 \%$ & 12 & $50 \%$ & 6 & $21 \%$ & 5 & $18 \%$ & 4 & $18 \%$ & 38 & $28 \%$ \\
\hline & Undergraduate & 6 & $40 \%$ & 7 & $44 \%$ & 2 & $8 \%$ & 11 & $38 \%$ & 15 & $53 \%$ & 7 & $32 \%$ & 48 & $36 \%$ \\
\hline & Postgraduate & & & & & 1 & $4 \%$ & 4 & $14 \%$ & 6 & $21 \%$ & 3 & $14 \%$ & 14 & $10 \%$ \\
\hline
\end{tabular}




\begin{tabular}{|c|c|c|c|c|c|c|c|c|c|c|c|c|c|c|c|}
\hline & Total & 15 & $100 \%$ & 16 & 1 & 24 & $100 \%$ & 29 & 1 & 28 & $100 \%$ & 22 & $100 \%$ & 134 & $100 \%$ \\
\hline \multirow{5}{*}{ 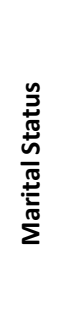 } & Married & 9 & $60 \%$ & 9 & $56 \%$ & 16 & $67 \%$ & 21 & $73 \%$ & 16 & $57 \%$ & 16 & $73 \%$ & 87 & $65 \%$ \\
\hline & Single & 5 & $33 \%$ & 3 & $19 \%$ & 3 & $12 \%$ & 7 & $24 \%$ & 12 & $43 \%$ & 5 & $23 \%$ & 35 & $26 \%$ \\
\hline & Divorced & 1 & $7 \%$ & 4 & $25 \%$ & 5 & $21 \%$ & 1 & $3 \%$ & & & & & 11 & $8 \%$ \\
\hline & Widow & & & & & & & & & & & 1 & $4 \%$ & 1 & $1 \%$ \\
\hline & Total & 15 & $100 \%$ & 16 & $100 \%$ & 24 & $100 \%$ & 29 & $100 \%$ & 28 & $100 \%$ & 22 & $100 \%$ & 134 & $100 \%$ \\
\hline & & & & & & & & & & & & & & & \\
\hline \multirow{8}{*}{ 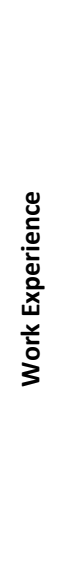 } & No & 3 & $20 \%$ & 2 & $12 \%$ & 4 & $17 \%$ & 7 & $24 \%$ & 3 & $11 \%$ & 5 & $23 \%$ & 24 & $18 \%$ \\
\hline & Yes & 12 & $80 \%$ & 14 & $88 \%$ & 20 & $83 \%$ & 22 & $76 \%$ & 25 & $89 \%$ & 17 & $77 \%$ & 110 & $82 \%$ \\
\hline & Less than 1 year & 2 & $25 \%$ & 1 & $7 \%$ & 1 & $6 \%$ & 0 & $0 \%$ & 3 & $14 \%$ & 1 & $6 \%$ & 8 & $8 \%$ \\
\hline & $1-3$ years & 3 & $38 \%$ & 0 & $0 \%$ & 6 & $33 \%$ & 5 & $23 \%$ & 4 & $19 \%$ & 0 & $0 \%$ & 18 & $18 \%$ \\
\hline & 3-5 years & 0 & $0 \%$ & 2 & $14 \%$ & 2 & $11 \%$ & 0 & $0 \%$ & 1 & $5 \%$ & 2 & $13 \%$ & 7 & $7 \%$ \\
\hline & $5-7$ years & 1 & $12 \%$ & 1 & $7 \%$ & 1 & $6 \%$ & 3 & $14 \%$ & 3 & $14 \%$ & 1 & $6 \%$ & 10 & $10 \%$ \\
\hline & $\begin{array}{l}\text { More than } 7 \\
\text { years }\end{array}$ & 2 & $25 \%$ & 10 & $72 \%$ & 8 & $44 \%$ & 14 & $63 \%$ & 10 & $48 \%$ & 12 & $75 \%$ & 56 & $57 \%$ \\
\hline & N/A & 4 & & 0 & & 2 & & 0 & & 4 & & 1 & & 11 & \\
\hline \multicolumn{2}{|c|}{$\begin{array}{l}\text { Average Number of } \\
\text { Children }\end{array}$} & \multicolumn{2}{|r|}{2.35} & \multicolumn{2}{|r|}{1.5} & \multicolumn{2}{|c|}{1.75} & \multicolumn{2}{|r|}{1.48} & \multicolumn{2}{|c|}{2.08} & \multicolumn{2}{|c|}{1.88} & \multicolumn{2}{|c|}{1.8} \\
\hline
\end{tabular}

\subsection{Respondents' Perception of Entrepreneurship, Their Motivation Factors and the Obstacles}

In the second section of this research, respondents were asked questions about their perceptions of expected knowledge and skills, their motivation sources, as well as the obstacles and opportunities that they could face while setting up a business. Mainly, regional differences among responses are checked. 5-point Likert scale questions were asked and analyzed on the basis of previous field research. In addition, the statements given in open-ended questions about the obstacles and opportunities that respondents could face while setting up business were evaluated. Results of the factor analysis on the knowledge and skills of a woman entrepreneur can be grouped in four dimensions: virtuousness, leadership, extroversion, and potential personal traits. The average points of respondents' sub-characteristics in each dimension fall between 4 (important) and 5 (very important). These four dimensions are presented below:

i. Virtuous characteristics: Being adaptive to context, being honest, trustworthy, brave, and patient.

ii. Leadership characteristics: Having management skills, being creative, risk-taking, innovative, ambitious, decided, and winner.

iii. Extroversive characteristics: Being curious, dreamer, extroversion, inclined to team work, and having communication skills.

iv. Potential personal traits: Educated, responsible, intelligent, loves her profession, well organized.

The highest average of responses among all these personal characteristics and inclinations can be listed in sequence as follows: "Being trustworthy" (4.8), "having communication skills" (4.8) and "being responsible" (4.7). In other words, "virtuousness" comes to the fore with the highest average (4.7) among all other identified dimensions.

Another subject explored in this research concerns the motivation factors leading women entrepreneur candidates to establish their own business. Reviewing the classification made by different scholars on this subject, it is seen that Barton and Martin (1998) divide motivation factors in three groups: personal traits, life conditions and contextual factors. Shapero 
and Sokol (1982); Sexton and Vasper (1982); Hisrich and Brush (1986) distinguish two groups of motivation factors: push and pull factors. Employment problems arising from economic conditions of the country, working conditions inappropriate for women, and discrimination of women in paid work can be listed among push factors. The desire for independence, selfrealization, self-employment, and balancing family and work can be considered among pull factors that lead women to establish their own business (cited from Okafor and Amalu, 2010).

The research results of this study show more correlation in particular subjects. The result of the factor analysis indicates that there are three main motivation factors leading women entrepreneur candidates to set up their own businesses. These factors are given below:

i) Personal Factors: Doing the job in which you were educated for, realizing an ideal, using skills, getting in business life, feeling self-worthy, working in more flexible working hours, being involved in trading

ii) Social-Familial Factors: Attaining social prestige, being an example for one's children, proving oneself, working in harmony with the spouse, being independent

iii) Financial Factors: Economic independence, contributing to the household income, escaping from financial difficulties, working after retirement

It is found that "the desire to be independent" (2.5) has the lowest average point among the listed motivation factors, while "realizing an ideal" (4.5) and "economic independence" (4.3) are factors with the highest average. At large, "personal factors" (4 important) has the highest average point in the category of motivation factors, while the lowest average is identified as "economic factors" (3.5).

It was also investigated whether there is a correlation between motivation factors, and knowledge and skills that women entrepreneurs are expected to have (correlation is significant at the 0.05 level (2-tailed)). The results of this correlation indicates that those respondents, who give importance to the leadership trait, value personal and social-familial factors the same, while valuing financial factors less (Respectively Sig=0.466 and $0.385<0.05$ ). Those who value extroversion lean towards entrepreneurship by being influenced more by social and familial reasons (Sig=0.468 <0.05). Respondents, who value potential (education, intelligence, and feeling fit for the job occupation), tend towards entrepreneurship by being more influenced by personal reasons ( $\mathrm{Sig}=0.443<0.05$ ). For respondents, who value personal characteristics such as trust, honesty and bravery categorized under "virtuousness", economic factors (Sig=0.405<0.05) constitute their entrepreneurship motivation the most. The reason why economic factors are found to be relatively lower among other motivation factors may arise from the fact that the research group consists of more urbanized and well educated individuals as well as individuals with work experience. In addition, personal factors relating to gender roles have a significant place in motivation factors leading women to establish their own business. This is an indicator of women's selfawareness about their strengths.

Previous researches investigating the obstacles or limits women may face when setting up a business pinpointed the following problems: being unable to carry out financial management, problems about monetary flow, being unexperienced and incompetent in management, lack of books and publications on the subject, problems about marketing and sales, being unable to form a team, experiencing problems with corporations/unions, not receiving expert views, limited social and business network, low demand in the local economy, systems and values about the right to property, problems in accessing financial resources, lack of work experience, skills and role models (Mayoux, 2001; United Nations, 2006-cited from Okafor and Amalu, 2010). Perceptions about potential problems rely on socio-economic indicators of the country as much as culture and values, which form the social capital, of that country. The results of that effect are clearly seen in the study on women entrepreneurship carried out by Minniti and Arenius (2003) in 37 countries. According to their research, factors influencing entrepreneurship were demographic context and family structure, literacy and education, socio-economic context, workforce and employment, gender and organizational forms, and sectoral employment and economic development.

The factor analysis in this research results grouped the obstacles or limitations which participants, as women individuals, may face in setting up new business under three different headings. These three identified obstacles are given below:

i) Personal shortcomings: Not having the necessary knowledge of the market, being inexperienced, having difficulties in accessing equipment and tools, being unable to keep up with new technologies, family disputes, having difficulty in finding a partner.

ii) Financial difficulty: Lack of capital, being unable to get a loan or credit.

iii) Contextual factors: Social values about women, bureaucratic barriers, value judgements of market conditions, difficulties about procuring personnel, difficulties in arranging the work place. 
Considering the average points of these dimensions, the strongest obstacle category expressed by respondents is financial difficulty (avg. 3.79). This is followed by contextual factors (avg. 3.51) and personal shortcomings (avg. 2.77). It is important to note that while financial factors are not in the forefront among respondents' motivation factors for becoming entrepreneurs, respondents highlight this financial dimension as a barrier. Considering the work experience of women, it may be argued that women do not have the necessary savings or they are anxious about transferring their existing saving to the business they are planning to establish.

When it is examined the correlation between the characteristics an entrepreneur and the obstacles for a women entrepreneur, the respondents who value potential identified contextual factors ( $\operatorname{Sig}=0.234<0.05)$ as obstacles that entrepreneurs will face. Considering the differences by cities in these three stage questions, the most significant difference (One-Way-ANOVA Sig ( $p$ value) $=0.002<0.05$ ) is found in "contextual factors" of obstacles that the respondents may face. The average points of "contextual factors" perceived as obstacles by women entrepreneurs are listed as follows: Konya (3.4), Kastamonu (3.8), İzmir (3.2), Gaziantep (3.5), Çanakkale (3.6) and Adana (3.4). Participants in the cities of İzmir, Konya and Adana reported that the barrier, which grouped under "contextual factor", has less effect on setting up a new business. Detailed information about contextual factors will be presented through participants' statements in the following section of this study. In order to complete these three stage questions, the advantages and disadvantages of the regions were analyzed. Here, the main motive was to find out whether the socio-economic and cultural structure of the city has any influence on this behavioural and ideational tenet. It was also desired to identify provincial divergences in shaping personal shortcomings or their choices. Responses to the open-ended questions on this matter are categorized and presented here in quotations.

According to the categorization of respondents' statements, results can be summarized as follows. The potential of a city is defined by market conditions, transportation, geographic structure, demographic conditions, gender characteristics, cultural and social structure and a familiar environment. Women's personal competence and their motivation to succeed is the primary factor, independent of a city's advantages. Overall, $24 \%$ of all respondents underlined this issue. In the second place, there is the statement - with a rate of $22 \%$ - that factors such as potential of the city, market conditions and transportation, and compactness of the city provide an advantage in establishing business. In the third place, there is the statement, expressed by $18 \%$ of all respondents, that cultural and social structure of a city creates a positive space for women's business and social lives. The last advantageous condition, expressed by participants, relates to the economic benefits and networks provided by the familiar environment of the city in establishing business. $10 \%$ of respondents underlined this point. The percentage of respondents who did not express any opinion on this issue is $19 \%$. The percentage of those, whose statements are outside the identified categories is $6 \%$.

It is important to note that respondents residing outside İmir and Çanakkale trust primarily in their own personal characteristics and tendencies, i.e. the power of their gender differences. It is also important to see the extent to which this power has an effect in identifying and fighting threat risks a city may bring. Within this context, the respondents' views about the perceived sources of negativity pertaining to the current socio-economic and cultural structure of their city were also analyzed. Their views on this issue were obtained through the categorization of open-ended questions. The results can be summarized as follows: cultural and social structure, incompetence, and lastly the potential of the city including its market conditions and demography. According to the results, values and beliefs, all of which are expressed as family pressure, male hegemony, conservative structure of the society, closed society, negative glances and the negative perception of women's role in the society, rank in the first with a percent rate of $36 \%$. Here, it is significant to note that patriarchal cities such as Konya, Kastamonu and Adana are at the forefront and no respondent from İzmir expressed any opinion on this issue. In the second place, there are views that focus on the issue of incompetence, such incompetence about knowledge, equipment and economy. Lastly, $13 \%$ of all respondents stated that economic and demographic structure of the city constitutes a disadvantage. While those residing in Çanakkale and Izmir mainly expressed that the city is not a disadvantage for them, respondents living in Konya, Kastamonu and Adana noted that the patriarchal and oppressive character of the city and its perception of women constitute a disadvantage. Respondents from the city Gaziantep, with a more introverted attitude, chose to share limited information and their opinions about the socio-economic structure and social capital of the city.

These results are in fact a projection of Turkey's social structure. Analysis of this projection is significant in understanding women entrepreneurs' motivation factors and obstacles they face in line with the socio-economic and cultural values of the region they reside in. In return, this understanding informs support mechanisms and planning activities that might ensure the permanence of entrepreneur candidates' motivation to establish their own businesses.

\subsection{Being a Woman Entrepreneur: Work or Family? Getting Lost in Between}

When positioning women in the sociocultural structure of Turkey, it is seen that the family-child-spouse triangle is of primary importance for women in Turkey in line with their gender roles. While this prioritization informs women's social behavioural patterns, it also influences their education, career plans, their sectoral choice and its quality. Problems about 
women's prioritization begin when the women start to step outside their normal routine. In addition, the pressure arising from cultural and social structures, i.e. the social capital of the society, make the pressure on women entrepreneurships about their household roles more visible. Within this context, considering that most of the respondents are married and have children, the finding about this pressure becomes crucial. More specifically, since the patriarchal family structure in Turkey is influential primarily in the rural area relatively in urban areas, a woman's household roles have importance in terms of family order for her spouse, family of her spouse and her own family. Even if the woman is not married, her "expected" household roles continue to be the same. Respondents' perception of the idea that women's integration to business life would prevent her from fulfilling her household roles sufficiently and the concern that traditional family union could be disintegrated is seen as a complementary research problem. Besides, the answers to questions on this issue will be influential in understanding both women's motivation factors and the entrepreneurship types they choose.

When it was asked to the respondents whether or not their household roles would be affected, a great majority - 56\% - of all participants stated that their household roles would be affected in a positive way. $41 \%$ of all respondents noted that their household roles would not be effected at all, whereas a very low rate as $3 \%$ of respondents stated that their household roles could be negatively affected. $81 \%$ of respondents from Izmir stated that their household roles would not be affected. Among six cities, Konya ranks the last with its $21 \%$ by stating that their roles would not be affected. Konya has the highest rate (75\%) with an expectation of positive change in their household roles, while in İzmir respondents did not identify any condition that could be defined as a positive effect. This finding is very significant. At large, $41 \%$ of all respondents claimed that their household roles will not change. It is believed that their prior experience in business life has an effect in these responses. Another reason for this response may lay in their perception that household roles will not change as long as they choose entrepreneurship type in line with the social capital of the city of residence.

The common ground for those, who expressed positively for their household roles, is the reflection of their awareness of personal motive for achievement, self-realization, self-knowledge and self-worth. The financial gain is not very apparent in the answers. This is related to women's prioritization to succeed, be respected in society and become a role model for their children.

Besides such positive effects, respondents were also asked whether or not being women entrepreneur candidates affected their household roles negatively. While statements about negative effects are very few, only $19 \%$ of respondents in izmir and $7 \%$ of respondents in Konya reported statements about such negative effects. In addition, the high average age of the respondent group means that their tasks as child bearers are fulfilled. This situation brings forward the feeling of fulfilling another need, i.e. being respected as a role model. Therefore, it is evident that the expectation about household roles evolves to another meaning.

In the last section this research, it was asked respondents' choice of female entrepreneurship types ${ }^{3}$ among the four definitions, namely innovative, conventional, radical and domestic (Goffe and Scase, 1985). 70\% of the correspondents responded as innovative entrepreneurship, $16 \%$ chose conventional entrepreneurship, while $11 \%$ stated that they were radical entrepreneurs and $3 \%$ of all respondents claimed that they were domestic entrepreneurs. It is seen that innovative type of entrepreneurship is most chosen in Çanakkale with a rate of $28 \%$ and this is followed by izmir with a rate of $25 \%$. For radical entrepreneurs Kastamonu ranks the first with a percent rate of 33\%, which is followed by Adana (14\%) and Gaziantep (11\%). There is an inverse relationship between advantages and disadvantages of the cities respondents reside. The desire to become radical entrepreneurs increases in the cities with the most social pressure towards women. The same rate is visible in the choice of conventional entrepreneurship. Çanakkale (28\%) and İzmir (25\%) are the first two cities with the highest rate of conventional entrepreneurship. Another data converging with this finding is the relationship between findings about the obstacles that those respondents may face when establishing a business and the entrepreneurship types. According to the previous findings, problems faced when establishing a business are grouped under three headings: personal shortcomings, financial difficulties and contextual factors. Values given to contextual factors significantly vary in line with entrepreneurship types (Sig=0,041<0.05).

There is no significant variance in different entrepreneurship types about financial difficulties and personal shortcomings (respectively; Sig=0.460 and $0.140<0.05$ ). However, different entrepreneurship types give varying values to contextual

\footnotetext{
${ }^{3}$ A conventional Entrepreneur pursues both entrepreneurial ideals and conventional gender roles. Trying to fulfill both simultaneously, this type of entrepreneurs balances work-family lives and they do not seek to expand their business too much. An Innovative Entrepreneur values her entrepreneurial ideals over conventional gender roles and expanding business is among her prioritized goals. A Domestic Entrepreneur values conventional gender roles above entrepreneurial ideals and perceives entrepreneurship merely as a subtask. A Radical Entrepreneur seeks to prevent exclusion of women in business life rather than maintaining the work-family balance. This type of entrepreneurs perceive work as a means to achieve this goal (Goffe and Scase, 1985 cited from Kutanis,2006)
} 
factors. The value given to contextual factors by entrepreneurship types can be listed in sequence as follows: radical entrepreneurs (3.9), domestic entrepreneurs (3.5), innovative entrepreneurs (3.2) and conventional entrepreneurs (2.7).

The respondents who choose innovative entrepreneurship explained their choice through statements such as life style, balancing work and career, goals, working in a respected business, being innovative and different. While those who choose domestic entrepreneurship highlighted the idea of not neglecting their families in explaining their choices. On the other hand, the respondents, who choose conventional entrepreneurship, underlined the difficulty of finding the balance between innate roles of a person and gender roles of women. Finally those who choose radical entrepreneurship pinpointed their desire for self-realization and independence against the exclusion of women.

When these findings of entrepreneurship types are compared with Kutanis's (2006) findings, it is seen that Turkish women display more the characteristics of conventional and domestic entrepreneurs. It is not clear whether these respondents will lean towards service industry based areas such as market research, advertising, public relations, education and media for the business they will set up in the future. Nevertheless, their high education levels ensure the precondition that their choice will be oriented towards this direction. In addition, the pressure deriving from contextual factors such as social oppression and household roles leads women to perceive "entrepreneurship" as a side job. In this way, they get squeezed in between conventional and domestic entrepreneurship types, one of the most significant obstacles against women's entrepreneurship.

\section{FINDINGS AND DISCUSSIONS}

Women's active participation in the economy is a significant factor in solving countries' economic problems. It should be noted that in Turkey, which has a fragile economy, women entrepreneurs could play a particularly important role in growing the economy, increasing employment and creating business on a global scale. Especially in countries with regularly increasing young and female populations like Turkey, women's active participation in economy is no longer a wish, but rather an imperative. Within this context, Turkey will have the power to increase the interest for women entrepreneurship with the design and success of its training programs for enhancing women entrepreneurship.

Considering that economic and sociological differences among regions in countries like Turkey have a great influence on women entrepreneurship. Age profile is a leading factor among demographic characteristics of women entrepreneurs. In countries like Turkey, the age at starting entrepreneurship for women is generally 35 and older. While this demographic finding is not a contribution to previous sociological studies on this matter, sustainable and consistent women entrepreneurship requires the integration of a younger population of women in entrepreneurship. Only then will entrepreneurship be a factor for economic and social integration for women.

Virtuousness, leadership, extroversion and potential personal characteristics are defined as characteristics of women entrepreneurship candidates by many scholars. Motivation factors leading women to become entrepreneurs are mainly informed by these personal traits. Self-realization is the primary factor motivating women in the process of setting up a business. Besides, social and financial motivation factors vary according to the perceived level of needs, socio-economic and cultural values of the region of residence. Another significant point is that the motivation power of financial factors diminishes as women's education level increases. High levels of financial expectations lead women to be more conventional and act more slowly in entrepreneurial activities. Obstacles constitute an important factor in women's choices for giving up entrepreneurship activities at an early stage. The scope and strength of these obstacles are related to social and economic structure of the city of residence. At this point, "patriarchal cities" - due to the patriarchal oppression on women - affect women's motivations in handling problems. Effects of patriarchal social structure in Turkey are clearly visible in the inability to sustain a regular increase in the number of women entrepreneurs. Under these circumstances, women's solidarity system has an informative mission. Another significant issue relates to the question of how women will utilize the perceived advantages of patriarchal cities against the feeling of despair created by this patriarchal pressure. In general, women develop social and economic awareness of the cities they live in; however, they have problems in transforming this awareness into business ideas. Here, the most crucial issue for women's entrepreneurship is the transformation of ideas into living and developing projects.

Women in Turkey tend to choose "conventional" and "domestic" entrepreneurship types. However, in early stages of entrepreneur candidacy, they sometimes choose the "innovative" type. The moment when women entrepreneur candidates begin to become independent entrepreneurs, their entrepreneurship plan changes. Although education levels of women entrepreneurs lead women to become "innovative" entrepreneurs, obstacles faced during the application of ideas change women's choices. Training programs designed for women's entrepreneurship need realistic planning and efforts for teaching women how an appropriate entrepreneurship model will be applied in all sectors from agriculture to manufacturing. If women are guided towards entrepreneurship without taking into account the existing conditions, their entrepreneurship stories will consist of short and repetitive episodes. Training programs for women require practices and support mechanisms i.e. guidance, finance, etc. and that can discover their ideas and merge these ideas with their skills. 


\section{CONCLUSION}

The study results were obtained from the participants of the education program in different cities prepared as one of the social and economic support mechanisms to increase women's entrepreneurship. The results implied that women who applied for the women entrepreneurship program strongly felt the effect of social gender norms despite their education levels and professional experience. Even though a relatively lower number of women expressed the effect of these norms in Western Turkey, their work plans are still affected by this social gender concerns. Regional differences affect the degree to which women feel the visible or invisible pressure of social gender norms. Social policies and strategies should be developed to be implemented along with educational programs in order to eliminate social gender-based barriers and ensure a holistic perspective. A sufficient number of female entrepreneurs to create an economic and social value cannot be achieved if a holistic approach cannot be ensured.

\section{REFERENCES}

Ecevit, Y. 1993, "Kadın Girişimciliğin Yaygınlaşmasına Yönelik Bir Model Önerisi (Recommendation of A Model on Making Women Entrepreneurship Widespread)", Kadını Girişimciliğe Özendirme ve Destekleme Paneli Bildiriler ve Tartışmalar (A Panel for Encouraging and Supporting Women to be Entrepreneurs; Papers and Discussions), Ministry of State Women and Social Services Undersecretariat General Directorate On The Status And Problems Of Women, Education Series, no. 74 ,pp. 15-34.

Karadeniz, E. 2014, "2013 ve 2014 Verileri ile Türkiye'de ve Bölgeler'de Girişimcilik (Entrepreneurship in Turkey and its Regions based on 2013 and 2014 Data)", GEM Turkey Report, http://www.kosgeb.gov.tr/Content/Upload/Dosya/Mali\%20Tablolar/GEM-2014.pdf.

Karim, N. A. 2015, "Jobs, Gender and Small Enterprises in Bangladesh: Factors Affecting Women Entrepreneurs in Small and Cottage Industries in Bangladesh" International Labour Organization. Retrieved from http://www.ilo.org/wcmsp5/groups/public/---ed_emp/--emp_ent/documents/publication/wcms_113774.pdf

Kelley,D., Slavica, S. \& Herrington, M. 2016, "2015/16 Global Report", Global Entrepreneurship Monitor, http://www.gemconsortium.org/report/49480.

Kelley,D., Herrington,M., Brush,C., Ali,A., Patricia,G. \& Kew P. 2015, “Women’s Entrepreneurship 2015”, GEM Special Report, http://gemconsortium.org/report/49281

Keskin, S. 2014, "Türkiye'de Kadın Girişimcilerin Durumu (Status of Women Entrepreneurs in Turkey)", Journal of Entrepreneurship and Development (9:1), pp. 72-94.

Özen Kutanis, R. "Girişimci kadınlar. (Women Entrepreneurs)" İstanbul: Değişim Publications (2006).

Küçük, E. 2015, "Kadın Eli Değmeyen Ülkelerde Ekonomik Kayıp Yüzde 30 (Economic Loss is 30\% in the Countries on Which Women Do Not 'Have A Hand')”, http://www.dunya.com/dunya/039kadin-eli039-degmeyen-ulkelerde-ekonomik-kayip-yuzde-30-haberi-273195

Morçin, E. S. 2013. "Türk Kültüründe Kadın Girişimciliği Kavramsal Bir Değerlendirme: Girişimci Tipleri (Woman Entrepreneurship In Turkish Culture: A Conceptual Evaluation)", Journal of Entrepreneurship and Development ,(8:2), pp. 167-191.

Minniti, M. \& Arenius, P. 2003, "Women In Entrepreneurship," The Entrepreneurial Advantage Of Nations: First Annual Global Entrepreneurship Symposium (United Nations Headquarters).

Okafor, C., and Amalu, R. 2010, "Entrepreneurial Motivations as Determinants of Women Entrepreneurship Challenges", Petroleum-Gas University of Ploiesti Bulletin, (62:2),pp. 67-77.

Saray, G. 1993, "Türkiye Esnaf-Sanatkâr ve Küçük işletmeler Kesimi ve Örgütlenmesi (Tradesmen-Craftsmen and Small Businesses in Turkey and Their Organization)", Kadını Girişimciliğe Özendirme ve Destekleme Paneli Bildiriler ve Tartışmalar (A Panel for Encouraging and Supporting Women to be Entrepreneurs; Papers and Discussions), Ministry of State Women and Social Services Undersecretariat General Directorate On The Status And Problems Of Women, Education Series, no:74

The Global Entrepreneurship Monitor (GEM) 2016 Results, http://www.yeditepe.edu.tr/en/news/global-entrepreneurship-monitor-gem2016-results-have-been-announced. 